\title{
Comparison of Life History Traits between First-Generation Hatchery and Wild Upper Yakima River Spring Chinook Salmon
}

\author{
CURTIS M. KNUDSEN* \\ Oncorh Consulting, 2623 Galloway SE, Olympia, Washington 98501, USA \\ Steve L. Schroder and Craig A. Busack \\ Washington Department of Fish and Wildlife, 600 Capitol Way North, \\ Olympia, Washington 98501-1091, USA \\ MARK V. JOHNSTON \\ Yakama Nation, Post Office Box 151, Toppenish, Washington 98948, USA \\ Todd N. Pearsons \\ Washington Department of Fish and Wildlife, 600 Capitol Way North, \\ Olympia, Washington 98501-1091, USA \\ William J. Bosch and David E. Fast \\ Yakama Nation, Post Office Box 151, Toppenish, Washington 98948, USA
}

\begin{abstract}
Life history traits in hatchery and wild spring Chinook salmon Oncorhynchus tshawytscha from the upper Yakima River were compared to determine whether locally adapted traits had diverged after one generation of state-of-the-art artificial propagation. Sex composition in wild- and hatchery-origin fish differed in three of four brood years $(P \leq 0.01)$. The proportion of hatchery males, primarily age 3 , increased from $38 \%$ to $49 \%$ over time. Conversely, the sex composition of wild fish did not exhibit a similar linear trend. Most hatchery- and wild-origin fish reached maturity at age $4(\geq 76 \%)$, followed in magnitude by ages 3 and 5. Wild mean age at maturation demonstrated no significant trend over time, while hatchery mean age at maturation declined $(P=0.05)$. Mean lengths of 3-5-year-old hatchery fish were shorter than those of wild fish of the same age (differences of $2.7 \mathrm{~cm}$ for age $3,1.7 \mathrm{~cm}$ for age 4 , and $1.9 \mathrm{~cm}$ for age 5). Likewise, body weights of hatchery fish were lower than those of wild fish (differences of $0.3 \mathrm{~kg}$ for age $3,0.3 \mathrm{~kg}$ for age 4 , and $0.6 \mathrm{~kg}$ for age 5), representing a change in body size of between 0.5 and 1.0 standard deviation (SD). Median arrival timing of hatchery and wild fish at a broodstock collection site just downstream of ancestral spawning grounds showed no consistent difference. However, the median arrival date of age-3 fish was 19-20 $\mathrm{d}$ later than that for fish of ages 4 and $5(P<0.01)$. Mean spawn timing of hatchery fish was significantly earlier $(5.1 \mathrm{~d})$ than that of wild fish in a "common-garden" experiment $(P<0.05)$. We estimate that fitness could be reduced by as much as $1-5 \%$ for traits diverging from their optima by $0.5-1.0 \mathrm{SD}$. The degree of genetic determination of the divergence is unknown, but future monitoring will help clarify this. Perhaps the most important conclusion of our study is that even a hatchery program designed to minimize differences between hatchery and wild fish did not produce fish that were identical to wild fish.
\end{abstract}

Artificial propagation of Pacific salmon Oncorhynchus spp. and steelhead $O$. mykiss has been practiced in the Pacific Northwest for over a century. Continuing losses of natural production from overharvest, habitat degradation, and disappearance of spawning habitat due to hydroelectric development, irrigation, logging, and transportation (Lichatowich 1999) have increased the importance of hatchery operations in the region. Over the past century, significant advances have been

\footnotetext{
* Corresponding author: knudsen@thurston.com
}

Received May 6, 2005; accepted March 2, 2006 Published online July 27, 2006 made in fish culture technology, and now spawnerrecruit rates in hatcheries often considerably exceed 1.0. However, what effect artificial production might have on native populations is unresolved (e.g., Waples et al., in press; Goodman 2005). This issue has become even more important recently because of the increasing use of "integrated" hatchery programs in which there is deliberate interbreeding of hatchery- and natural-origin fish (Goodman 2004; Mobrand et al. 2005). In the Columbia River basin, for example, approximately one-third of the nearly 200 hatchery programs currently in place are considered supplementation operations (Goodman 2004) and thus involve some level of 
interbreeding between hatchery- and natural-origin fish. Aspects of the genetic risks of integrated programs have been modeled (Lynch and O'Hely 2001; Ford 2002; Goodman 2005) and the demographic risks of integrated programs recognized (Goodman 2004; Mobrand et al. 2005), but empirical assessments of integrated programs are lacking, as illustrated by a recent review (Berejikian and Ford 2004) that compared the fitness of natural- and hatchery-origin fish. Seventeen of the 18 studies reviewed examined the effects of intentional selection, multiple generation effects, use of nonlocal broodstock, or combinations of these factors. Only one study (Blouin 2003) dealt with conditions that could be considered relevant to the concept of integrated hatchery programs.

The program analyzed by Blouin (2003) and more recently described by Araki et al. (in press) exclusively used natural-origin steelhead as broodstock. In this regard it is not unlike several other extant and pending programs that have restricted broodstock to naturalorigin fish or established criteria for the proportion of hatchery-origin adults allowed on spawning grounds. To evaluate the risks and benefits posed by integrated programs, appropriate demographic and genetic data need to be collected (Hard 1995). Whenever possible, data collection should start at the beginning of a program to document whether first-generation hatchery fish are diverging from their native population. Evaluation at this time is critical because progeny of naturally spawning hatchery fish may possess characteristics that are intermediate between those possessed by wild- and hatchery-origin individuals. Consequently, when such individuals are compared with hatchery fish, differences between their traits will be less than those that may occur between pure wild and hatchery individuals.

Life history traits reflect local adaptations affecting population productivity and individual fitness (Stearns 1976; Roff 1992; Brannon et al. 2004). Changes in demographic or life history traits (such as a reduction in age-classes or skewed sex ratio) can reduce phenotypic variation and affect total annual egg production and effective population size (Nunney 1991; Waples 2002). Moreover, changes in adult spawn timing may reduce fitness by shifting fry emergence timing outside a locally adapted temporal window (Brannon 1987; Smoker et al. 1998; Einum and Fleming 2000; Brannon et al. 2004). In general, significant changes in locally adapted life history traits will be maladaptive in the wild (Lynch and O'Hely 2001; Ford 2002; Goodman 2004, 2005), leading to reduced individual reproductive success (Taylor 1991; Fleming and Gross 1993; Fleming et al. 2000) and possibly resulting in lower productivity of a naturally spawning population. Monitoring life history traits of hatchery populations to determine if they are diverging from their native population's distributions is a necessary part of a hatchery monitoring plan (Hard 1995; Goodman 2005). Significant differences may indicate that the artificial rearing environment is causing genetic divergence to occur between the two groups. However, phenotypic changes alone are not sufficient to conclude that genotypic divergence has occurred. To do that, fish from both groups should be spawned, incubated, and reared in a common environment. Observed differences under these circumstances would represent genetic change.

In 1997, an integrated hatchery program was begun to supplement the upper Yakima River population of spring Chinook salmon O. tshawytscha (Fast and Craig 1997). The program used only natural-origin fish as broodstock, and no attempt was made to control the proportion of hatchery-origin fish on the spawning grounds. Passage and hatchery facilities in the Yakima River provide excellent access to fish, so our approach has been to measure a variety of fitness-related life history traits on adult returns at different locations in the river. This paper describes the integrated hatchery program targeted on the upper Yakima River and reports on differences between wild-origin and firstgeneration hatchery-origin fish at several adult life history traits: age and sex composition, size at age, and migration and spawn timing. Finally, we discuss the probable origins of the differences we observed: whether they were genetic with serious implications for long-term impacts (Lynch and O'Hely 2001; Goodman 2004) or simply the result of phenotypic differences caused by hatchery rearing practices.

\section{Methods}

Yakima River spring Chinook salmon and the Yakima spring Chinook salmon enhancement project.-The Yakima River is a large tributary to the Columbia River located in south-central Washington State (Figure 1). It contains three genetically distinct wild spring Chinook salmon populations (Busack and Marshall 1991) that are reproductively isolated in both space and time: the American River (a tributary of the Naches River), the Naches River basin (excluding the American River), and the upper Yakima River (Figure 1). These three populations exhibit significant differences in spawn timing, age composition, and size at age (Major and Mighell 1969), as well as sex composition (Knudsen et al. 2005). All three populations are "stream-type" Chinook salmon (Healey 1991); adults migrate into the basin in the spring and spawn in the early fall, and juveniles spend a full year in freshwater before migrating to the ocean. Some 


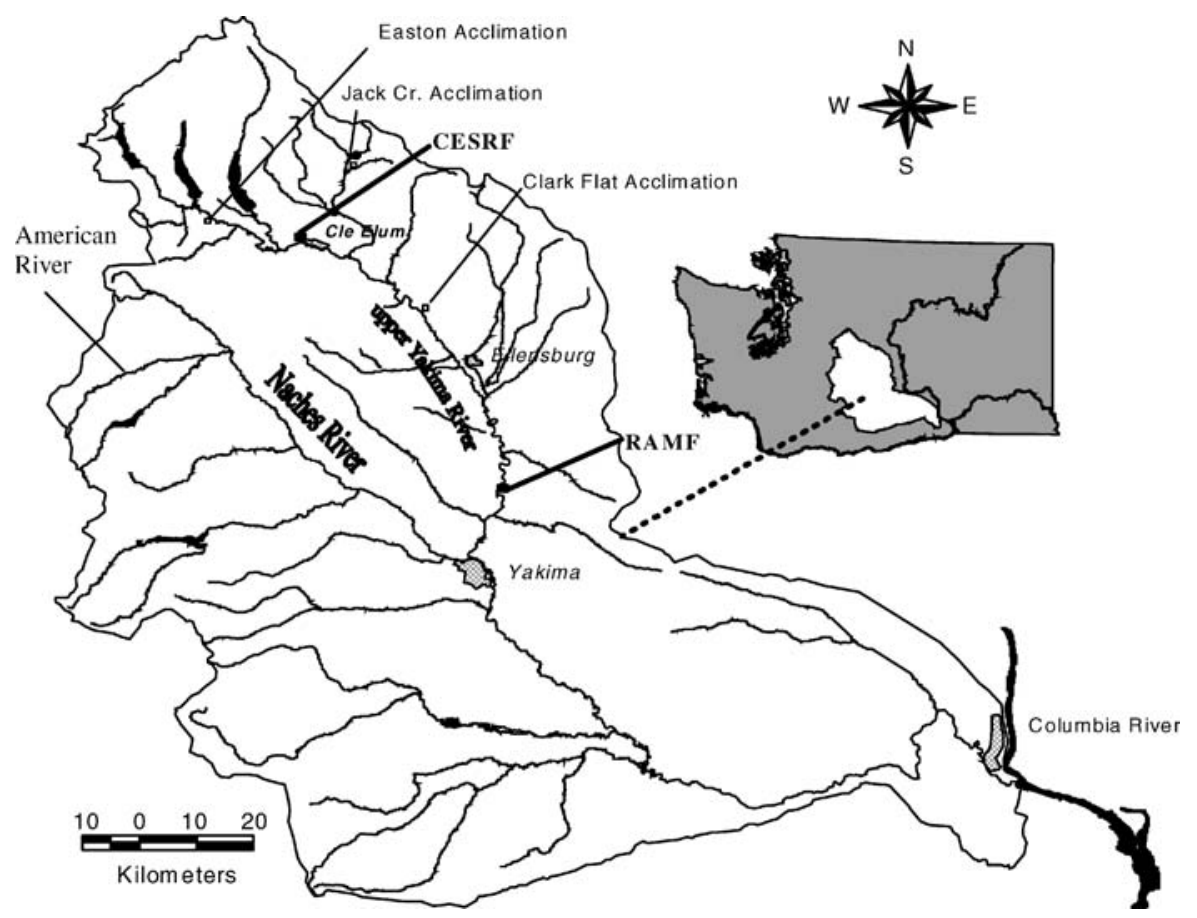

FIGURE 1.-Map of the Yakima River basin, Washington, showing the upper Yakima River, Roza Adult Monitoring Facility (RAMF), Cle Elum Supplementation Research Facility (CESRF), spring Chinook salmon acclimation sites, Naches River, and the American River.

males mature precociously in freshwater in their first or second year (see Larsen et al. [2004] and Pearsons et al. [2004] for a full description of hatchery and wild precocious male production in the upper Yakima River).

The Yakima-Klickitat Fishery Project (YKFP) began a spring Chinook salmon hatchery program at the Cle Elum Supplementation Research Facility (CESRF) near Cle Elum on the upper Yakima River (river kilometer [rkm] 297, measuring from the confluence with the Columbia River; Figure 1) in 1997. This program is a supplementation effort targeting the upper Yakima River population and is designed to test whether artificial propagation can be used to increase natural production and harvest opportunities while limiting ecological and genetic impacts. It is an integrated hatchery program (Mobrand et al. 2005) because only natural-origin broodstock are used and returning hatchery-origin adults are allowed to spawn in the wild. The program includes a domestication monitoring effort that compares several traits of the supplemented population with those of a hatchery-only control line founded from first-generation hatchery returns, and with those of a wild control line (the unsupplemented Naches River population; Busack et al. 2004).

A note on nomenclature is in order at this point. As integrated programs proceed, it is inappropriate to call fish resulting from natural spawning "wild" because they may be the progeny of naturally spawning hatchery fish. These fish are more appropriately called "natural-origin" fish. We call the naturally produced fish in this study wild because they occurred before significant numbers of naturally produced fish of hatchery ancestry were possible (Table 1). Hatcheryorigin, age-3 males from the 1997 brood year (BY) may have made some contribution to the 2000 brood, but this influence was probably slight as these fish accounted for only 5\% of the natural spawning population (Yakama Nation [YN], unpublished data). The natural-origin upper Yakima River spring Chinook salmon in this study can be considered wild also because this population had been subjected to only negligible levels of hatchery activity in the past.

Broodstock collection and fish culture.-Broodstock were collected exclusively from wild adults between 1997 and 2000 at the Roza Adult Monitoring Facility (RAMF) located adjacent to Roza Dam (rkm 206; Figure 1). Roza Dam is an irrigation diversion structure 
TABLE 1.-Degree of hatchery ancestry among natural-origin spring Chinook salmon from the upper Yakima River through the first three generations of integrated hatchery operation. Data are shown for return years 2000-2008, which correspond to brood years 1997-2005. Entries are fish ages at return. Those in ordinary type indicate fish with wild ancestry only, whereas those in bold italics indicate fish with substantial hatchery ancestry. The one entry with an asterisk indicates fish with a small hatchery influence from age-3 males (see text for further details).

\begin{tabular}{|c|c|c|c|c|c|c|c|c|c|c|c|c|}
\hline \multirow{2}{*}{$\begin{array}{c}\text { Brood } \\
\text { year }\end{array}$} & \multicolumn{4}{|c|}{$\begin{array}{c}\text { Generation } 1 \\
\text { (Initiation of hatchery operations } \\
\text { and broodstock collection) }\end{array}$} & \multicolumn{4}{|c|}{$\begin{array}{c}\text { Generation } 2 \\
\text { (Hatchery fish begin } \\
\text { returning to spawn naturally) }\end{array}$} & \multicolumn{4}{|c|}{$\begin{array}{c}\text { Generation } 3 \\
\text { (First returns of } \\
\text { natural-origin fish produced by } \\
\text { naturally spawning hatchery fish) }\end{array}$} \\
\hline & 1997 & 1998 & 1999 & 2000 & 2001 & 2002 & 2003 & 2004 & 2005 & 2006 & 2007 & 2008 \\
\hline 1997 & & & & 3 & 4 & 5 & & & & & & \\
\hline 1998 & & & & & 3 & 4 & 5 & & & & & \\
\hline 1999 & & & & & & 3 & 4 & 5 & & & & \\
\hline 2000 & & & & & & & 3 & 4 & 5 & & & \\
\hline 2001 & & & & & & & & 3* & 4 & 5 & & \\
\hline 2002 & & & & & & & & & 3 & 4 & 5 & \\
\hline 2003 & & & & & & & & & & 3 & 4 & 5 \\
\hline 2004 & & & & & & & & & & & 3 & 4 \\
\hline 2005 & & & & & & & & & & & & 3 \\
\hline
\end{tabular}

that all upper Yakima River salmon must pass through before reaching their spawning grounds. The RAMF was operated daily between April and September. No more than $50 \%$ of the wild fish collected on any given day at RAMF were used as broodstock. All returning fish were enumerated, and a subsample was selected and taken by truck to CESRF, where they were held until they reached maturity. Most fish collected were used as broodstock for the supplemented line or for the hatchery control line, but additional wild- and hatchery-origin fish were collected at RAMF for other research purposes. All fish transferred to CESRF were tagged with passive integrated transponder (PIT) tags (Prentice et al. 1990) in the pelvic girdle at RAMF so that individual data collected at the two sites could be linked. Considerable attention was paid to collecting fish randomly over the entire run. In 1997 and 1998, broodstock was collected randomly based on a list of random numbers developed from the broodstock need and the predicted run size. This method, however, created the potential for significant over- or undercollecting if run predictions were inaccurate. For this reason, from 1999 onward broodstock collection has been based on average migration timing patterns past RAMF (Bosch 2005). We used the same method for hatchery-origin adults, which began returning in 2001.

It was not possible to collect broodstock by sex at RAMF because adults pass RAMF $1-5$ months prior to reaching full maturity and consequently have not fully developed their distinguishing secondary sexual characteristics. For this reason, we collected two age-size categories of broodstock: age-4 and older returns (where sex identification was ambiguous) and age-3 returns, which could be accurately identified based on their significantly smaller body size and which were known to be nearly all males (Washington Department of Fish and Wildlife [WDFW] and YN, unpublished data).

Hatchery and wild adults transferred to CESRF were held together in a single concrete raceway until reaching maturity and then artificially spawned. Fertilized eggs from each female were sequestered from one another until they reached the eyed stage of development. By that time, pathogen screenings were completed. Eggs from females deemed to be pathogen free were combined and placed into Heath trays supplied with rugose substrate and incubated until yolk absorption. After completion of the incubation period, fry were transferred and reared in concrete raceways ( $30 \mathrm{~m}$ long $\times 3.3 \mathrm{~m}$ wide $\times 3.1 \mathrm{~m}$ deep) with a water flow of $2,200 \mathrm{~L} / \mathrm{min}$ for approximately 16 months and then were moved to three acclimation sites (Figure 1) for an additional 8-10 weeks of rearing. Mean rearing densities ranged annually from approximately 36,000 to 46,000 fish per raceway. In midMarch, raceway screens were pulled and fish were allowed to volitionally emigrate over the following 2 months. Total smolt releases ranged from 370,000834,000 fish for BYs 1997-2000, and fork lengths and

TABLE 2.-Mean hatchery smolt body weights and fork lengths by brood year for upper Yakima River spring Chinook salmon. Fish were sampled just prior to the initiation of volitional releases from the acclimation sites.

\begin{tabular}{llccr}
\hline $\begin{array}{c}\text { Brood } \\
\text { year }\end{array}$ & Sample date & $\begin{array}{c}\text { Body } \\
\text { weight }(\mathrm{g})\end{array}$ & $\begin{array}{c}\text { Fork } \\
\text { length }(\mathrm{mm})\end{array}$ & \multicolumn{1}{c}{$N$} \\
\hline 1997 & Mar 11 1999 & 17.9 & 116.7 & 654 \\
1998 & Mar 13 2000 & 15.6 & 111.6 & 1,007 \\
1999 & Mar 12 2001 & 18.5 & 118.6 & 1,078 \\
2000 & Mar 18 2002 & 20.1 & 121.7 & 1,079 \\
\hline
\end{tabular}


body weights averaged between 115 and $122 \mathrm{~mm}$ and 17.2 and $20.1 \mathrm{~g}$, respectively, in mid-March as volitional releases began (Table 2). In mid-May, any juveniles still remaining at the acclimation sites were forced out of their raceways. The first release of hatchery yearling smolts occurred in 1999. All hatchery releases were adipose fin clipped for postrelease monitoring and to allow unambiguous identification of hatchery fish upon return as adults.

Data collection.-Both wild and hatchery adults were sampled at two sites each year. At RAMF, passage date, body length, weight, and age data were collected as fish migrated upstream. At CESRF, maturation date and gender were noted as fish were artificially spawned, and these data were linked back to the fish's RAMF passage date, size data, and age data by means of an adult PIT tag applied at RAMF.

Upstream migrants were processed daily at RAMF over the course of the run each year. All hatchery fish were identified by their missing adipose fins and were diverted to a holding tank containing an anesthetic solution of MS-222 (tricaine methanesulfonate; Bell 1964) at a concentration of approximately 130-260 mg of MS-222/L of water. Each fish was examined for marks and tags and was visually classified as either age 3 or older based on body size; some were sampled for additional biological information. The proportion $(0.10-0.25)$ of hatchery fish selected for biological sampling depended on the magnitude of the forecasted run size. Selected hatchery fish were measured for postorbital hypural plate (POHP) length, body weight, age (scale sample), and arrival date at RAMF. After being sampled, fish were briefly held to recover from the anesthetic and released back to the river to complete their spawning migration or transferred to CESRF if they had been selected as potential broodstock or for other purposes. Similarly, all the wild fish selected for broodstock were anesthetized, measured, and weighed at RAMF before being transferred to CESRF.

Sex and age composition.-Estimates of the percentages of adult females and males passing RAMF were made on the basis of fish collected at RAMF and taken to CESRF, where sex was identified by post mortem inspections of wild fish selected for broodstock and wild and hatchery adults that met other experimental needs. As mentioned above, fish transferred to CESRF were intramuscularly PIT-tagged in the pelvic girdle, allowing them to be linked back to their collection date at RAMF. This ability to link individual fish back to when they were sampled at RAMF allowed us to identify the sex of the fish and therefore to estimate age-specific sex ratios for each return year. These ratios were then multiplied by age-specific RAMF return numbers to calculate age- and sex-specific total return numbers. Fish produced in any particular BY returned at age 3, 4, or 5. Data were organized on a BY basis for both sex and age composition analyses. Comparisons of hatchery and wild sex composition were made for each BY using a $\chi^{2}$ test with Yates correction (Zar 1999).

As noted above, age- 3 returns (jacks) were identified by their significantly smaller body size. The age composition of wild age- 4 and age-5 adults was estimated from fish taken to CESRF. Acetate impressions were made from scales that had been placed on labeled gummed cards, and ages were determined by examining the impressions using a microfiche reader. Two scale analysts independently aged all scales and resolved disagreements. Ages were designated as the number of years from conception (BY) to return year. Thus, a fish produced from parents spawning in the fall of 1998 and returning in 2003 is identified as age 5. We evaluated temporal trends in age structure by regressing age-class proportions over the four BYs.

All means were calculated as unweighted averages, and all statistical tests were considered significant if the $P$-value was 0.05 or less.

Size at age.-Lengths and body weights of wildorigin fish were taken when the fish arrived at RAMF, and size data for hatchery-origin fish were also collected at RAMF. This was done to ensure that both types of fish would be in similar stages of maturity when size measurements were made. Within each BY, hatchery and wild size-at-age distributions were compared by age-class by means of a two-way analysis of variance (ANOVA; origin $\times$ year). If the interaction effect was significant $(P<0.05)$, we performed a $t$-test for each BY to examine origin effects. Sexual dimorphism in size is common in Pacific salmon and does occur in the Naches and American River populations of spring Chinook salmon; however, upper Yakima hatchery- and natural-origin adults do not exhibit significant sexual dimorphism in either body weight or length (WDFW and YN, unpublished data). Therefore, males and females were combined within age-classes in all body size analyses.

Adult passage timing.-We analyzed passage timing by return year rather than BY, because although populations of adult Pacific salmon demonstrate consistent patterns in upstream migration timing, there can be significant year-to-year variation resulting from interannual differences in river discharge (Keefer et al. 2004) and ocean water temperature regimes (Hodgson and Quinn 2002). Passage data were obtained by recording when fish were passed upstream through RAMF. We compared hatchery and wild passage timing distributions but grouped returns into two types 


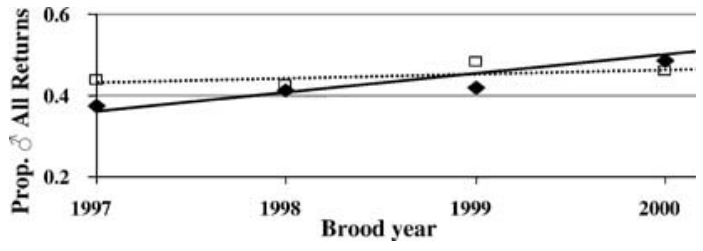

FIGURE 2.-Proportion of hatchery (diamonds; solid line) and wild (squares; dashed line) spring Chinook salmon returns to the upper Yakima River, Washington, composed of males, by brood year.

for analysis: age 3 and ages 4 and 5 combined. The data were analyzed with a three-way ANOVA testing for origin (hatchery, wild), type (age 3, ages 4-5), and year (2001-2004) effects, as well as interactions. All RAMF passage dates were converted to ordinal dates (day of year). The passage dates were $\log _{e}$ transformed to normalize distributions during analyses.

Adult spawn timing.-We were able to use a "common-garden" experiment to test for differences in maturation timing at CESRF because hatchery- and wild-origin adults were held together in a single concrete raceway. Beginning in early September and continuing into early October, adults were checked for ripeness and were spawned weekly. Ripe fish were identified when either eggs or milt were extruded with gentle manual pressure; fish were then transferred to a separate raceway for holding until spawning the next day. Hatchery- and wild-origin spawn timing distributions were compared with a three-way ANOVA (origin $X$ return year $X$ sex). For these analyses, we divided sex into three categories: age- 3 males, age- 4 males, and age- 4 females. As with passage date and for the same reasons, analysis was done on a return year rather than BY basis, and all dates were converted to ordinal dates. Spawn timing appeared to be normally distributed, so dates were not $\log _{e}$ transformed. Age-5 returns were not included because they were not represented by one or both sexes in some years and represented $1-6 \%$ of total returns.

Exploration of fitness impacts.-The fitness cost of differences between wild- and hatchery-origin fish for traits in which standard deviations could be estimated was explored using Lande's (1976) stabilizing selection model for quantitative variation, in which fitness declines in a Gaussian pattern as trait value deviates from an optimum. The severity of the fitness loss depends on the strength of selection. Mean fitness in the notation of Ford (2002) is given by

$$
\bar{W} \propto \exp \left[\frac{-(\bar{z}-\theta)^{2}}{2\left(\omega^{2}+\sigma^{2}\right)}\right],
$$

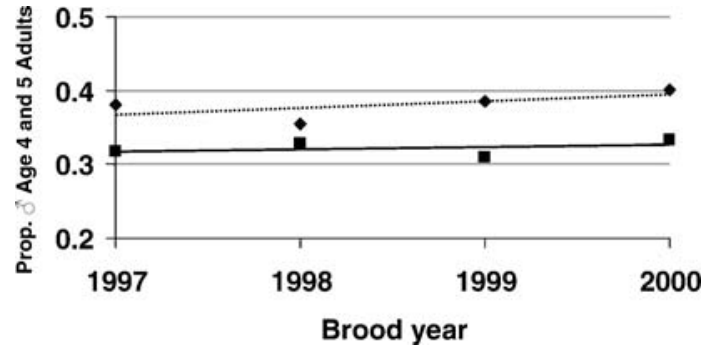

FIGURE 3.- The proportion of male spring Chinook salmon returns (ages 4 and 5 only) to the upper Yakima River, Washington, by origin (wild [squares; solid line] or hatchery [diamonds; dashed line]) and brood year.

where $\bar{z}$ is the mean trait value, $\theta$ is the optimum trait value, $\omega$ is the selection intensity, and $\sigma^{2}$ is the trait variance. We assumed that the wild component of the population was at the optimum.

\section{Results}

\section{Sex Composition}

The proportions of female and male wild- and hatchery-origin adults differed significantly in three of four BYs ( $\chi^{2}$ tests; BY 1997 and 1999-2000: $P<$ 0.01; BY 1998: $P=0.192$ ). Females were predominant in wild returns in all years, while the proportion of hatchery males steadily increased from 0.38 to 0.49 (Figure 2; hatchery linear regression: $P=0.049, r^{2}=$ $0.855)$. Conversely, wild returns showed no significant trend in the proportion of males over time (linear regression: $P=0.388$ ). When just age- 4 and age-5 returns were examined, the proportion of males for both hatchery and wild returns showed no trend over time (wild linear regression: $P=0.386$; hatchery regression: $P=0.638$; Figure 3 ), indicating that the trend in increasing proportion of males over time was a consequence of the increase in age- 3 returns. However, the proportion of age- 4 and age- 5 males was always lower in the hatchery returns than in the wild returns by an average of 0.06 .

\section{Age Composition}

The majority of hatchery- and wild-origin fish within a brood returned at age 4 ( $\geq 76 \%$; Table 3$)$, followed, in descending order, by ages 3 and 5 . In three of four BYs, hatchery- and wild-origin age compositions were significantly different $(P<0.01$; Table 4$)$. There were significant temporal trends in hatchery age composition that were not observed in wild age composition. In general, for wild-origin adults, the proportion of fish returning at ages 3 and 4 showed no temporal trend over BYs (all wild-origin linear regressions: $P \geq 0.61$ ). In contrast, the proportion of age- 3 hatchery returns 
TABLE 3.-Age and sex composition of upper Yakima River wild- and hatchery-origin spring Chinook salmon by brood year based on scales and mark recoveries at the Roza Adult Monitoring Facility (RAMF) or the Cle Elum Supplementation Research Facility (CESRF). Sample sizes for sexing are in parentheses and represent fish examined post mortem at CESRF.

\begin{tabular}{|c|c|c|c|c|c|}
\hline Origin & $\begin{array}{c}\text { Brood } \\
\text { year }\end{array}$ & Age & $\begin{array}{c}\text { Age-class } \\
(\%)^{\mathrm{a}}\end{array}$ & $\begin{array}{l}\text { Male } \\
(\%)\end{array}$ & $\begin{array}{c}\text { Female } \\
(\%)\end{array}$ \\
\hline \multirow[t]{12}{*}{ Wild } & \multirow[t]{3}{*}{1997} & 3 & 9.4 & $9.4(41)$ & $0.0(0)$ \\
\hline & & 4 & 88.3 & $33.5(181)$ & $54.8(297)$ \\
\hline & & 5 & 2.3 & $1.0(12)$ & $1.3(17)$ \\
\hline & \multirow[t]{3}{*}{1998} & 3 & 12.8 & $11.6(28)$ & $1.2(2)$ \\
\hline & & 4 & 82.8 & 29.2 (177) & $53.6(325)$ \\
\hline & & 5 & 4.3 & $1.7(25)$ & $2.6(38)$ \\
\hline & \multirow[t]{3}{*}{1999} & 3 & 17.4 & $16.5(37)$ & $0.9(2)$ \\
\hline & & 4 & 77.8 & $30.3(121)$ & 47.5 (190) \\
\hline & & 5 & 4.8 & $1.6(1)$ & $3.2(2)$ \\
\hline & \multirow[t]{3}{*}{2000} & 3 & 9.9 & $9.9(55)$ & $0.0(0)$ \\
\hline & & 4 & 88.7 & $35.6(202)$ & $53.1(302)$ \\
\hline & & 5 & 1.4 & $0.5(3)$ & $0.9(5)$ \\
\hline \multirow[t]{12}{*}{ Hatchery } & \multirow[t]{3}{*}{1997} & 3 & 8.5 & $8.5^{\mathrm{b}}$ & 0.0 \\
\hline & & 4 & 89.4 & $28.4(35)$ & $61.0(75)$ \\
\hline & & 5 & 2.1 & 0.7 (1) & $1.4(2)$ \\
\hline & \multirow[t]{3}{*}{1998} & 3 & 12.7 & $12.7(5)$ & $0.0(0)$ \\
\hline & & 4 & 81.3 & 25.9 (57) & 55.4 (113) \\
\hline & & 5 & 6.0 & $2.7(21)$ & $3.3(26)$ \\
\hline & \multirow[t]{3}{*}{1999} & 3 & 15.9 & $15.9(10)$ & $0.0(0)$ \\
\hline & & 4 & 82.2 & $26.1(25)$ & $56.1(41)$ \\
\hline & & 5 & 1.9 & $0.0(0)$ & 1.9 (2) \\
\hline & \multirow[t]{3}{*}{2000} & 3 & 22.9 & 22.9 (26) & $0.0(0)$ \\
\hline & & 4 & 75.6 & $25.3(37)$ & $50.3(60)$ \\
\hline & & 5 & 1.5 & $0.4(2)$ & $1.1(5)$ \\
\hline
\end{tabular}

${ }^{a}$ For ages 4 and 5, age-class was determined from scales and tags or marks. Age-3 percentages are based on visual counts as fish passed RAMF. Age- 4 and age- 5 percentages were then adjusted to account for the age- 3 component.

${ }^{\mathrm{b}}$ No brood year 1997 hatchery age- 3 returns were taken to CESRF for post mortem sexing. All were assumed to be males.

significantly increased over time (regression: $P=$ $0.003, r^{2}=0.912$; Figure 4), more than doubling from 0.09 to 0.23 . The wild and hatchery proportions of age3 returns were nearly identical for the first three BYs and then deviated sharply in 2000 , driving the trend observed in hatchery returns in Figure 4 . The increase in the proportion of hatchery age-3 returns (nearly exclusively male) resulted in a significant decrease in hatchery mean age at maturation over time (regression:

TABLE 4.-Age composition $\chi^{2}$ test results for origin (hatchery-wild) effects by brood year for upper Yakima River spring Chinook salmon. The sexes were combined within ageclasses.

\begin{tabular}{cr}
\hline Brood year & \multicolumn{1}{c}{$P$} \\
\hline 1997 & 0.072 \\
1998 & 0.002 \\
1999 & 0.002 \\
2000 & $<0.001$ \\
\hline
\end{tabular}

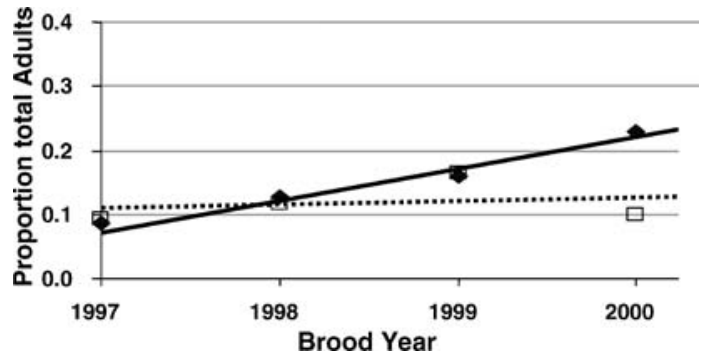

FIGURE 4.-The proportion of spring Chinook salmon adults returning as age- 3 spawners to the upper Yakima River, Washington, by origin (wild [squares; dashed line] or hatchery [diamonds; solid line]) and brood year.

$P=0.05, r^{2}=0.85$ ), while wild mean age at maturation showed no trend (regression: $P=0.55$ ).

Size at Age

The mean POHP lengths and body weights of hatchery- and wild-origin returns by BY and age are given in Table 5 along with sample sizes and standard deviations (SDs). For each BY, age-3 hatchery returns were smaller than wild-origin age- 3 returns (length and body weight ANOVAs, origin effects: $P<0.001$; Table 6). On average, hatchery age-3 fish were $2.7 \mathrm{~cm}$ and $0.3 \mathrm{~kg}$ smaller than wild-origin fish, representing

TABLE 5.- Mean postorbital hypural plate (POHP) lengths $(\mathrm{cm})$, body weights (BW, kg), and sample sizes $(N)$ of hatchery- and wild-origin spring Chinook salmon returns to the upper Yakima River for brood years 1997-2000.

\begin{tabular}{|c|c|c|c|c|c|}
\hline $\begin{array}{l}\text { Brood } \\
\text { year }\end{array}$ & Age & Origin & POHP (SD) & BW (SD) & $N$ \\
\hline \multirow[t]{6}{*}{1997} & \multirow[t]{2}{*}{3} & Hatchery & $38.3(3.8)$ & $1.2(0.4)$ & 635 \\
\hline & & Wild & $41.3(3.5)$ & $1.5(0.4)$ & 41 \\
\hline & \multirow[t]{2}{*}{4} & Hatchery & $59.3(4.0)$ & $4.3(0.8)$ & 2,342 \\
\hline & & Wild & $61.3(4.2)$ & $4.6(0.9)$ & 483 \\
\hline & \multirow[t]{2}{*}{5} & Hatchery & $67.0(6.3)$ & $5.8(1.4)$ & 34 \\
\hline & & Wild & $71.2(4.0)$ & $7.1(2.0)$ & 30 \\
\hline \multirow[t]{6}{*}{1998} & \multirow[t]{2}{*}{3} & Hatchery & $39.9(3.5)$ & $1.4(0.4)$ & 473 \\
\hline & & Wild & $42.9(3.1)$ & $1.7(0.4)$ & 32 \\
\hline & \multirow[t]{2}{*}{4} & Hatchery & $59.2(3.8)$ & $4.1(0.8)$ & 1,535 \\
\hline & & Wild & $60.9(3.6)$ & $4.5(0.8)$ & 535 \\
\hline & \multirow[t]{2}{*}{5} & Hatchery & $71.4(4.1)$ & $6.8(1.2)$ & 215 \\
\hline & & Wild & $72.3(4.5)$ & $7.1(1.3)$ & 62 \\
\hline \multirow[t]{6}{*}{1999} & \multirow[t]{2}{*}{3} & Hatchery & $38.7(4.1)$ & $1.2(0.4)$ & 26 \\
\hline & & Wild & $41.6(4.0)$ & $1.5(0.4)$ & 46 \\
\hline & \multirow[t]{2}{*}{4} & Hatchery & $60.6(4.4)$ & $4.4(1.0)$ & 255 \\
\hline & & Wild & $62.4(4.3)$ & $4.7(0.9)$ & 312 \\
\hline & \multirow[t]{2}{*}{5} & Hatchery & $71.0(2.8)$ & $5.9(0.8)$ & 2 \\
\hline & & Wild & $69.3(2.5)$ & $6.2(0.1)$ & 3 \\
\hline \multirow[t]{6}{*}{2000} & \multirow[t]{2}{*}{3} & Hatchery & $41.8(3.7)$ & $1.5(0.4)$ & 394 \\
\hline & & Wild & $43.5(3.7)$ & $1.6(0.5)$ & 55 \\
\hline & \multirow[t]{2}{*}{4} & Hatchery & $59.5(3.9)$ & $4.1(0.8)$ & 451 \\
\hline & & Wild & $59.8(4.1)$ & $4.1(0.8)$ & 515 \\
\hline & \multirow[t]{2}{*}{5} & Hatchery & $70.1(3.8)$ & $6.4(1.6)$ & 18 \\
\hline & & Wild & $70.8(5.2)$ & $6.5(1.9)$ & 12 \\
\hline
\end{tabular}


TABLE 6.-Comparisons of postorbital hypural plate (POHP) length and body weight distributions of age-3 Yakima River spring Chinook salmon returns using a two-way ANOVA (origin $\times$ brood year [BY]) of hatchery and wild origin for BYs 1997-2000.

\begin{tabular}{lrrrrr}
\hline \multicolumn{1}{c}{ Source } & $\begin{array}{l}\text { Sum of } \\
\text { squares }\end{array}$ & df & $\begin{array}{r}\text { Mean } \\
\text { square }\end{array}$ & $F$-ratio & $P$ \\
\hline \multicolumn{5}{c}{ POHP length } \\
Origin & 801.60 & 1 & 801.60 & 58.57 & $<0.001$ \\
BY & 761.81 & 3 & 253.94 & 18.55 & $<0.001$ \\
Origin $\times$ BY & 57.63 & 3 & 19.21 & 1.40 & 0.240 \\
Error & $23,184.60$ & 1,694 & 13.69 & & \\
\multicolumn{5}{c}{ Body weight } \\
Origin & 6.15 & 1 & 6.15 & 39.09 & $<0.001$ \\
BY & 6.09 & 3 & 2.03 & 12.90 & $<0.001$ \\
Origin $\times$ BY & 1.11 & 3 & 0.37 & 2.36 & 0.070 \\
Error & 266.62 & 1,694 & 0.16 & & \\
\hline
\end{tabular}

a divergence from wild distributions of between 0.5 and 1.0 SD. Hatchery age- 4 fish were also $1.5 \mathrm{~cm}$ shorter and $0.3 \mathrm{~kg}$ lighter on average than wild-origin returns except in BY 2000. The mean differences represent a shift in body size distributions of up to $0.5 \mathrm{SD}$. Initial analysis of age-4 size distributions using a two-way ANOVA (origin $\times$ BY effects) indicated there were significant origin $(P<0.001)$, BY $(P<0.001)$, and origin $\times \mathrm{BY}$ interaction $(P<0.001)$ effects; the interaction was obviously caused by BY 2000 . We then reanalyzed the age-4 length and body weight distributions by BY using a $t$-test to assess origin effects. Wild returns were significantly larger than hatchery returns in all BYs but 2000 (POHP length and body weight $t$ test: $P<0.001)$. In 2000, wild fish were longer but not significantly so ( $t$-test: $P=0.223)$ and were equal in body weight to hatchery returns ( $t$-test: $P=0.967)$. The sample size for age-5 fish in BY 1999 was very small,

TABLE 7.- Two-way ANOVA results comparing postorbital hypural plate (POHP) length and body weight distributions of age-5 hatchery- and wild-origin spring Chinook salmon returns to the upper Yakima River for brood years (BYs) 1997, 1998, and 2000.

\begin{tabular}{lrrrrr}
\hline \multicolumn{1}{c}{ Source } & $\begin{array}{r}\text { Sum of } \\
\text { squares }\end{array}$ & df & $\begin{array}{r}\text { Mean } \\
\text { square }\end{array}$ & $F$-ratio & $P$ \\
\hline \multicolumn{5}{c}{ POHP length } \\
Origin & 117.75 & 1 & 117.75 & 6.09 & 0.014 \\
BY & 324.02 & 2 & 162.01 & 8.38 & $<0.001$ \\
Origin $\times$ BY & 95.32 & 2 & 47.66 & 2.46 & 0.086 \\
Error & $7,059.28$ & 365 & 19.34 & & \\
& \multicolumn{7}{c}{ Body weight } \\
Origin & 13.230 & 1 & 13.230 & 7.429 & 0.007 \\
BY & 15.890 & 2 & 7.945 & 4.461 & 0.012 \\
Origin $\times$ BY & 12.731 & 2 & 6.365 & 3.574 & 0.029 \\
Error & 650.029 & 365 & 1.781 & & \\
\hline
\end{tabular}

TABLE 8.- Three-way ANOVA results of the $\log _{e}$ transferred passage date of spring Chinook salmon at the Roza Adult Monitoring Facility on the upper Yakima River. The ANOVA tested for effects of origin (hatchery versus wild), type (age 3 versus ages 4-5), return year (RY; 2001-2004), and all interactions.

\begin{tabular}{lrrrrr}
\hline \multicolumn{1}{c}{ Source } & $\begin{array}{c}\text { Sum of } \\
\text { squares }\end{array}$ & df & $\begin{array}{c}\text { Mean } \\
\text { square }\end{array}$ & $F$-ratio & $P$ \\
\hline $\mathrm{RY}$ & 0.453 & 3 & 0.151 & 4.254 & 0.005 \\
Type & 0.187 & 1 & 0.187 & 5.258 & 0.022 \\
Origin & 0.082 & 1 & 0.082 & 2.312 & 0.129 \\
$\mathrm{RY} \times$ type & 0.170 & 3 & 0.057 & 1.600 & 0.187 \\
$\mathrm{RY} \times$ origin & 0.042 & 3 & 0.014 & 0.391 & 0.759 \\
Type $\times$ origin & 0.009 & 1 & 0.009 & 0.258 & 0.612 \\
$\mathrm{RY} \times$ type $\times$ origin & 0.063 & 3 & 0.021 & 0.593 & 0.620 \\
Error & 49.322 & 1,390 & 0.035 & & \\
\hline
\end{tabular}

so we limited the age-5 analysis to BYs 1997, 1998, and 2000. Within those BYs, age-5 wild fish were significantly larger than hatchery returns: $1.9 \mathrm{~cm}$ larger and $0.6 \mathrm{~kg}$ heavier (length and body weight ANOVAs, origin effects: $P<0.01$; Table 7). These differences represent an average divergence in trait distributions of approximately $0.4 \mathrm{SD}$.

\section{Passage Timing}

Hatchery and wild passage timing at RAMF did not differ significantly in the three-way ANOVA (origin effects: $P=0.129$; Table 8 ), and hatchery and wild median passage timing followed no consistent pattern across years (Table 9). We did find that age-4 and age5 adults passed RAMF on average $19 \mathrm{~d}$ earlier than did age- 3 adults (average difference over return years and origins; type effect: $P=0.022$ ). There were also significant return year effects $(P=0.005)$, driven to a large degree by later passage in 2002 .

\section{Spawn Timing}

Beginning with the first hatchery-origin age-4 adults artificially spawned at CESRF in 2001, hatchery returns have matured significantly earlier than wild fish (origin: $P<0.001$; Table 10), spawning 5.1 $\mathrm{d}$ earlier on average than wild fish (Table 11). Contrary to fish origin, age of maturation within hatchery or wild fish did not affect when the fish matured, as spawn timing of age-3 and age- 4 males and females were similar (sex effect: $P=0.113$ ). The observed difference in spawn timing was equal to approximately $0.7 \mathrm{SD}$.

\section{Exploration of Fitness Impacts}

On the basis of recent reviews, Hard (2004) concludes that selection intensity $(\omega)$ for life history traits is unlikely to be outside the range of 1-4 SD. Application of Lande's (1976) model with these values suggests that the differences in body size and spawn 
TABlE 9.- Median passage timing (day of year) of hatchery- and wild-origin spring Chinook salmon at the Roza Adult Monitoring Facility (RAMF), Yakima River, for age-3 and age-4-5 returns (types used in three-way ANOVA in Table 8). Sample sizes $(N)$ are total age-5 returns passing RAMF; na $=$ not applicable.

\begin{tabular}{|c|c|c|c|c|}
\hline Type & Return year & Origin & Median & $N$ \\
\hline \multirow[t]{10}{*}{ Age 3} & \multirow[t]{2}{*}{2000} & Wild & 166.5 & 474 \\
\hline & & Hatchery & 164.0 & 618 \\
\hline & \multirow[t]{2}{*}{2001} & Wild & 160.0 & 336 \\
\hline & & Hatchery & 167.0 & 990 \\
\hline & \multirow[t]{2}{*}{2002} & Wild & 175.0 & 131 \\
\hline & & Hatchery & 177.5 & 86 \\
\hline & \multirow[t]{2}{*}{2003} & Wild & 167.0 & 774 \\
\hline & & Hatchery & 166.0 & 1,133 \\
\hline & \multirow[t]{2}{*}{2004} & Wild & 159.0 & 711 \\
\hline & & Hatchery & 163.0 & 216 \\
\hline \multirow[t]{10}{*}{ Ages 4-5 } & \multirow[t]{2}{*}{2000} & Wild & 142.0 & 10,619 \\
\hline & & Hatchery ${ }^{\mathrm{a}}$ & na & \\
\hline & \multirow[t]{2}{*}{2001} & Wild & 142.0 & 5,010 \\
\hline & & Hatchery $^{\mathrm{b}}$ & 145.0 & 6,1808 \\
\hline & \multirow[t]{2}{*}{2002} & Wild & 160.0 & 2,361 \\
\hline & & Hatchery & 163.0 & 6,133 \\
\hline & \multirow[t]{2}{*}{2003} & Wild & 146.0 & 784 \\
\hline & & Hatchery & 144.0 & 1,151 \\
\hline & \multirow[t]{2}{*}{2004} & Wild & 141.0 & 7,144 \\
\hline & & Hatchery & 143.0 & 2,985 \\
\hline
\end{tabular}

${ }^{\text {a }}$ No age -4 or age -5 returns occurred in this year.

${ }^{\mathrm{b}}$ No age- 4 returns occurred in this year.

timing $(\bar{z}-\theta)$ observed in this study $(0.5-1.0 \mathrm{SD})$ would equate to a relative fitness of approximately 77 $99 \%$ for a single trait. For the more-likely $\omega$ range of 3-4 SD (Hard 2004), the relative fitness range would be $95-99 \%$.

\section{Discussion}

\section{Sex Composition}

While females were predominant in wild returns in all years and showed no trend over time, the proportion of hatchery males steadily increased over time. It appears some facet of hatchery rearing incrementally

TABLE 10.- Three-way ANOVA of spawn timing for spring Chinook salmon in the upper Yakima River. The ANOVA tested for the effects of year, origin (hatchery, wild), and sex (age-4 males, age- 4 females, and age- 3 jacks) and all possible interactions.

\begin{tabular}{lrrrrr}
\hline \multicolumn{1}{c}{ Source } & $\begin{array}{c}\text { Sum of } \\
\text { squares }\end{array}$ & df & $\begin{array}{r}\text { Mean } \\
\text { square }\end{array}$ & $F$-ratio & \multicolumn{1}{c}{$P$} \\
\hline Origin & $3,604.0$ & 1 & $3,604.0$ & 67.0 & $<0.001$ \\
Year & $1,028.9$ & 4 & 257.2 & 4.8 & 0.001 \\
Sex & 235.4 & 2 & 117.7 & 2.2 & 0.113 \\
Year $\times$ sex & 639.5 & 8 & 79.9 & 1.5 & 0.157 \\
Year $\times$ origin & 224.0 & 4 & 56.0 & 1.0 & 0.385 \\
Sex $\times$ origin & 12.2 & 2 & 6.1 & 0.1 & 0.893 \\
Year $\times$ sex $\times$ origin & 276.8 & 8 & 34.6 & 0.6 & 0.742 \\
Error & $114,653.5$ & 2,130 & 53.8 & & \\
\hline
\end{tabular}

TABLE 11.-Mean spawning date (day of year) for hatcheryand wild-origin spring Chinook salmon in the upper Yakima River. Ages and sexes are combined because there were no significant differences between age-3 returns (primarily males), age-4 males, and age-4 females (Table 10), which represent between $94 \%$ and $99 \%$ of all returns.

\begin{tabular}{llllr}
\hline Return year & Origin & Mean & SD & $N$ \\
\hline \multirow{2}{*}{2001} & Hatchery & 256.9 & 7.3 & 79 \\
& Wild & 261.3 & 8.0 & 413 \\
2002 & Hatchery & 260.5 & 7.2 & 92 \\
& Wild & 267.9 & 7.2 & 385 \\
2003 & Hatchery & 259.8 & 6.8 & 127 \\
& Wild & 266.0 & 7.8 & 369 \\
2004 & Hatchery & 262.8 & 8.4 & 60 \\
& Wild & 265.2 & 6.7 & 347 \\
\hline
\end{tabular}

increased the portion of fish maturing as age-3 males. When we examined the mean fork lengths of migrating hatchery and wild smolts captured in a juvenile trap at Roza Dam during March 15 to May 21 between 1999 (BY 1997) and 2002 (BY 2000), we noticed two trends: (1) there was an increasing difference in length between hatchery and wild smolts and (2) hatchery smolts were stable in size over time, while naturalorigin smolts decreased in size over time (Figure 5). Larger juvenile size at release can result in increased production of age-3 males (jacks) in Chinook salmon (Vøllestad et al. 2004), but mean release sizes of CESRF juveniles did not increase steadily over time (Table 2) and in-river hatchery smolt samples demonstrated a flat temporal trend in length (Figure 5) that does not parallel the increase in hatchery age-3 production. In addition, while mean wild smolt lengths decreased over time likely as a result of densitydependent interactions (Pearsons et al. 2004), the proportion of wild age-3 adults produced from these BYs remained relatively stable over time. All of this indicates that smolt length does not appear to be a good predictor of age-3 male production in upper Yakima

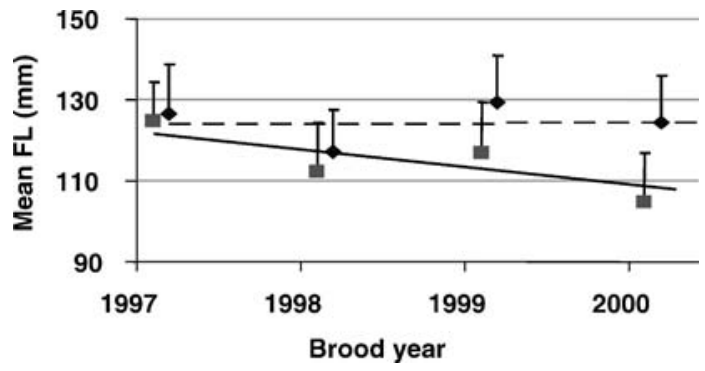

FIGURE 5.-Mean + SD fork lengths (FLs) of hatchery (diamonds; dashed line) and wild (squares; solid line) spring Chinook salmon smolts sampled at the Roza Dam smolt trap on the Yakima River, Washington. 
River hatchery or wild returns. The female-skewed sex ratios of both hatchery and wild age- 4 and age- 5 returns are in large part attributable to age-1 (wild) and age-2 (wild and hatchery) nonanadromous precocious males and to age-3 returns maturing and thus not contributing to the older male age-classes in the cohort. Larsen et al. (2004) estimated that the CESRF hatchery produced significantly more age- 2 precocious males than the naturally spawning wild population, which produced both age-1 and age- 2 precocious males (Pearsons et al. 2004). Larsen et al. (2004) hypothesized that in hatchery-origin adults, the increased production of precocious males should result in a sex ratio that is even more highly skewed toward females, since naturally spawning precocious males are unlikely to survive postspawning and therefore "drop out" of a cohort. Our results do not support this hypothesis and indicate that just the opposite appears to be occurring: the proportion of males is increasing in adult hatchery BY returns over time primarily because of increasing proportions of age-3 hatchery males.

\section{Age Composition}

We observed a consistent flat temporal trend in wild age composition by BY, indicating that the upper Yakima River wild population has maintained a stable age distribution, perhaps due to stabilizing selection. Reduced mean age at maturity of hatchery fish due to increases in the proportion of hatchery age- 3 returns has been observed in other spring Chinook salmon hatchery programs (Hankin 1990) such as those in the Tucannon (Gallinat 2004), Grand Ronde (Carmichael and Messmer 1995), and Wenatchee (Murdoch et al. 2005) rivers. The cause of the increase in age- 3 males in the YKFP is unclear as discussed above, and smolt length does not appear to explain the trend.

One factor that differs in wild and hatchery juvenile populations is the capacity of wild fish to migrate from their rearing areas at any time during the year. Wild juvenile passage at a downstream juvenile trap occurs over a much broader temporal period and begins earlier than the hatchery juvenile out-migration (unpublished data). Hatchery juvenile releases do not begin until mid-March, 3-4 months after wild juvenile Chinook salmon have begun moving downstream in the Yakima River (Bosch 2005). Perhaps the restriction of hatchery smolt movements and the constraint to a later migration period have enhanced the occurrence of age- 3 fish. We are unsure why such an increase has occurred and will continue to monitor this trend in the future.

\section{Size at Age}

The magnitude of the one-generation shift in length and body weight distributions represents a response of approximately $0.4-1.0 \mathrm{SD} /$ generation. These exceed rates of declining body size in Chinook salmon populations observed by Ricker (1995) and Bigler et al. (1996). In fish that mature at multiple ages, such as Chinook salmon, decreases in average body size can be due to either reduced mean age at maturation, such as when older age-classes are fished out in newly exploited populations, or decreases in growth reflected in lower size at age. Since the changes we observed were changes in size at age, they represent decreases in growth rate. Adult size at age is subject to environmentally driven phenotypic plasticity (Riddell 1986; Hard 1995), such as the growth response to the ocean environment (Wells et al. 2006), and can also be significantly affected by size and time of smolt releases in hatchery programs (Bilton 1980). Size at age and growth rate are also influenced by both natural and sexual selection pressures (Quinn and Foote 1994; Hendry 2001) and have been shown to respond to selection (Gjerde and Gjedrem 1984; Su et al. 2002). Irrespective of causes, smaller body size can reduce maternal fitness by (1) adversely affecting a female's ability to compete in the wild for nest sites and to construct and guard redds (van den Berghe and Gross 1989; Foote 1990); (2) decreasing redd depth, thereby increasing redd vulnerability to scour during flood events (van den Berghe and Gross 1989; Steen and Quinn 1999); and (3) reducing mean fecundity (Healey and Heard 1985; Beacham and Murray 1993). Smaller body size can also influence spawning distribution by reducing the ability of fish to colonize more-distant or higher-elevation spawning areas (Beacham and Murray 1993; Kinnison et al. 2001) and larger portions of river systems (Rogers 1987; Blair et al. 1993; Hendry and Quinn 1997). In addition, lower mean body weight also reduces the average carcass biomass returning to the natal basin, potentially reducing exogenous nutrients available to rearing juveniles (Bilby et al. 1996); however, this would only be a significant problem if nutrients are limiting production and demographic benefits of supplementation are not realized.

The observed difference in POHP length between first-generation hatchery- and natural-origin fish is similar to the results reported in three other hatchery projects using natural-origin broodstock: Tucannon River spring Chinook salmon, Sacramento winter Chinook salmon, and Cedar River sockeye salmon $O$. nerka. Tucannon River hatchery-origin returns were smaller at age during the initial years of operation (Gallinat 2004). The Sacramento River winter Chinook salmon program has been in operation at some level since 1989. In 2003, hatchery-origin females were on average $1.3 \mathrm{~cm}$ shorter in fork length $(\sim 0.33 \mathrm{SD})$ than natural-origin females, and hatchery-origin males were 
on average $4.9 \mathrm{~cm}$ shorter $(\sim 0.75 \mathrm{SD})$ than naturalorigin males (USFWS 2004). Fresh et al. (2003) found that the mean POHP length of first-generation age-4 Cedar River hatchery sockeye salmon females was 1.5 $\mathrm{cm}$ shorter than that of wild conspecifics. In addition, Unwin and Glova (1997) found that New Zealand hatchery-reared male Chinook salmon returned $0.6 \mathrm{~cm}$ smaller than natural-origin males.

In both the Tucannon River and New Zealand studies, hatchery fish were much larger at juvenile release than their natural-origin counterparts, and this larger size was probably the primary cause of the observed difference in size at age. As noted above (see also Figure 5), CESRF spring Chinook salmon smolts are larger than upper Yakima River wild smolts migrating contemporaneously and, due to wild smolt size decreasing over time, the difference between hatchery and wild smolt sizes increases over time. Thus, if smolt size is affecting adult size, we would expect (1) the difference in hatchery and wild adult body sizes to increase over time and (2) the wild body size at age to decrease (reflecting the trend in Figure 6). However, these trends were not observed. Thus, it does not appear that differences in smolt size would cause the observed differences in adult body size.

It is clear, however, that because size differences were consistently observed in age- 3 fish, the causal mechanism(s) responsible for the shift in size distribution must act during the 18 months between juvenile release and return at maturation. One possibility is that the hatchery juveniles undergo a period of depressed growth while they transition to natural food sources, and subsequent growth never entirely compensates for this energy deficit. Another is that hatchery-origin juveniles out-migrate more slowly than natural-origin juveniles, arriving in marine waters later. Bilton (1980) noted that earlier releases of coho salmon $O$. kisutch returned at a larger size because they had the opportunity to rear for a longer period in the moreproductive marine environment.

One strong selection factor that could impact the trait distributions of CESRF returns are the hatcheryselective fisheries in the lower Columbia River that target adipose fin-clipped hatchery fish. If these fisheries selectively remove larger hatchery fish, they could shift the size distribution of survivors lower. However, the commercial and sport hatchery-selective fisheries did not occur until 2002 (WDFW and ODFW 2002) and thus did not interact with hatchery-origin age-3 returns from BYs 1997 and 1998 and age-4 returns from BY 1997. Since we observed that each of these hatchery groups was significantly smaller than wild returns, it does not appear that lower Columbia
River hatchery-selective fisheries could be responsible for the divergence in body size.

\section{Passage and Spawn Timing}

Run and spawn timing have been shown to be heritable traits in salmonids (Siitonen and Gall 1989; Smoker et al. 1998; Quinn et al. 2002). After one generation of hatchery influence, we observed significant differences between hatchery and wild fish passing RAMF, and median passage dates of hatchery fish lagged by $3 \mathrm{~d}$ on average. Passage at RAMF occurs over approximately 5 months, so a lag in median passage timing of $3 \mathrm{~d}$ is unlikely to have a significant impact on the reproductive success of naturally spawning hatchery fish because we found no correlation between RAMF passage date and date of maturation. More noteworthy was the consistent, significantly earlier maturation of hatchery fish relative to wild fish after being held in a common vessel under the same environmental conditions. Earlier maturation was also noted by Quinn et al. (2002) in three Chinook salmon hatcheries and was attributed to inadvertent selection. A shift toward earlier hatchery maturation timing advances embryo development through additional development days, resulting in early hatchery fry emergence. Based on September 2000-2004 upper Yakima River mean daily water temperatures, eggs that were spawned $5.2 \mathrm{~d}$ earlier than the mean natural spawning date would acquire $77^{\circ} \mathrm{C}$ in additional temperature units. This should result in earlier emergence timing, which could cause higher mortality for the early emerging fish due to suboptimal rearing conditions. Conversely, early emergence could allow hatchery fry to establish prior residence when early rearing condition are better than average, allowing them to displace wild fry downstream from preferred rearing areas (Berejikian et al. 1996; Rhodes and Quinn 1998).

\section{Fitness Implications}

The development of differences in traits between hatchery- and natural-origin fish derived from the same native stock may have a significant genetic component as a result of domestication, either through unintentional directional selection or relaxation of natural selection pressures in the hatchery (Hard 1995; Lynch and O'Hely 2001; Ford 2002). They may also be caused by phenotypic plasticity due to environmental variation (Stearns 1989) or result from a complex interaction of both factors (Riddell 1986; Taylor 1991; Hard 1995). Irrespective of the underlying causes, whether genetic or environmental, a significant shift in body size and maturation timing from the locally adapted optimum will result, on average, in some loss 
in overall productivity of naturally spawning hatchery fish through selection against the smallest and earliest spawners and a reduction in the proportion of largest and latest spawners.

A complete analysis for the traits considered here would need to evaluate all the traits simultaneously as well as other correlated traits (e.g., fecundity, egg size, fry size, and fry emergence timing) in a multivariate treatment such as in Lande (1980); this would include accounting for phenotypic and genetic covariation between traits (see Hard 2004 for an example). However, if hatchery-origin fish differ phenotypically from the optimum at several traits, each of which depresses fitness by approximately $5 \%$, the overall effect could be considerable. For example, differences at four traits could depress fitness by nearly $20 \%$, which could seriously affect the demography of a supplementation program (Goodman 2004).

It is likely that counterselection operating in the wild would act on hatchery fish representing the extremes of the divergent traits; in the absence of an infusion of hatchery-origin spawners each year, natural selection would eventually drive trait distributions back toward their locally adapted optima over generations (Lande and Arnold 1983; Law 1991; Hendry 2001). However, the intent is to have the Yakima River supplementation program be an integrated program with a constant infusion of hatchery-origin spawners each year and to use natural-origin fish only as hatchery broodstock. Such programs should incur less domestication than traditional hatchery programs with heavy gene flow from the hatchery to the natural-origin component and little gene flow in the other direction (Goodman 2004).

\section{Results in Perspective}

We would like to conclude by putting these results in the context of the continuous debate over the risks and benefits of artificial propagation, especially integrated hatchery programs, in recovery efforts. In numerous ways, the YKFP spring Chinook salmon program is designed to minimize genetic impacts. Only naturalorigin broodstock, collected randomly over the course of the run, is used. The relative size of the program (adult returns) is limited so as not to overwhelm the naturally spawning population (Lynch and O'Hely 2001; Ford 2002). No more than $50 \%$ of the naturalorigin returns can be used as broodstock. Factorial matings (Fiumera et al. 2004; DuPont-Nivet et al. 2006) are used in the hatchery to increase effective population size and maintain genetic diversity. The proportion of age- 3 males that are taken as broodstock is limited to historical BY levels. Additionally, "best culture practices," such as low rearing densities and volitional release of juveniles, are used. The intent is to increase natural production of spring Chinook salmon while at the same time producing hatchery returns that are equivalent to naturally produced returns in terms of life history and reproductive success, at rates comparable to their natural-origin conspecifics. Our purpose as researchers is to intensively monitor this program from its inception to assess how well it meets these objectives.

This hatchery program is in the beginning of its third generation (Table 1). The first hatchery fish have returned to spawn in the wild, and their naturally produced progeny have begun to return (Pearsons 2002). At this point, the program appears to be successful in producing returning hatchery adults, yielding as many as 33 recruits per spawner (authors' unpublished data), but it is too early to determine its success at increasing natural production. In this study, we reported that the first-generation hatchery returns in this program differ from their wild counterparts at size at age, age and sex composition, and spawn timing. These differences are large enough to potentially have some effect on fitness, but at this point the magnitude of that effect and the impact on overall population productivity are unclear. Araki et al. (in press) determined through a pedigree study that first-generation hatchery steelhead in the Hood River, Oregon, were just as fit as their wild counterparts. It is plausible that in our program, the total effect of all differences between wild and hatchery fish (as well as effects we did not observe) amount to a similar quantity of fitness change. Also unclear in our study is the degree of genetic determination of these differences. A common assumption in criticizing hatcheries is that any changes observed as a result of hatchery culture are genetic; in fact, such changes may be the result of a mix of genetic and environmental causes. We would not be surprised to learn that the changes we have observed are largely environmental in origin. Comparing future generations of returns with our hatchery control line should allow us to partition the effects into genetic and nongenetic causes.

In the meantime, perhaps the most important observation to be derived from this study is that hatcheries do not produce fish that are identical to wild fish, even in a program designed to minimize the differences between the two production types. The early hatchery and natural rearing environments experienced by upper Yakima River spring Chinook salmon differ sufficiently to cause differences of $0.5-$ 1.0 SD after 2.5 years of growth in a common environment. The significance of these differences is unclear, but as some of them have been observed in several programs, their implications for population productivity clearly need to be better understood as we 
proceed with the use of conservation hatcheries to sustain salmon and steelhead production.

\section{Acknowledgments}

We thank the following YN-RAMF personnel: Joe Hoptowit, Gerry Lewis, Ray Decoteau, Antoine Marek, Jamie Bill, Jackson James, Leroy Senator, Seymour Billy, Wayne Smartlowit, Morales Ganuelas, Ted Matin, and Sarah Sohappy. Their diligence and effort are greatly appreciated. In addition, we would like to thank Dan Barrett, Charlie Strom, Jason Rau, and Annie Joe Parrish, CESRF, for their help during the spawning season. Paul Huffman and Bruce Watson (YN) participated in sampling broodstock at CESRF. T. Swan (YN) and J. Sneva (WDFW) aged all the scale samples. Conversations with Bruce Watson (YN) and Bill Hopley (WDFW) early in project development were very helpful. We thank Kevin Niemela and Bob Null (U.S. Fish and Wildlife Service [USFWS]) for information on Sacramento River winter Chinook salmon. John Easterbrooks (WDFW) and Mel Sampson (YN) provided policy support, and the Bonneville Power Administration (BPA) provided funding to the YKFP. David Byrnes (BPA) was instrumental in securing and administering funding. Bill Conners (USFWS) and two anonymous reviewers provided helpful editorial comments.

\section{References}

Araki, H., R. Arden, E. Olsen, B. Cooper, and M. S. Blouin. In press. Reproductive success of captive-bred steelhead trout in the wild: evaluation of three hatchery programs in the Hood River. Conservation Biology.

Beacham, T. D., and C. B. Murray. 1993. Fecundity and egg size variation in North American Pacific salmon (Oncorhynchus). Journal of Fish Biology 42:485-508.

Bell, G. R. 1964. A guide to the properties, characteristics, and uses of some general anaesthetics for fish. Fisheries Research Board Canada Bulletin 148:1-4.

Berejikian, B. A., S. B. Mathews, and T. P. Quinn. 1996. Effects of hatchery and wild ancestry and rearing environments on the development of agonistic behavior in steelhead trout (Oncorhynchus mykiss) fry. Canadian Journal of Fisheries and Aquatic Sciences 53:2004-2014.

Berejikian, B. A., and M. J. Ford. 2004. Review of relative fitness of hatchery and natural salmon. NOAA Technical Memorandum NMFS-NWFSC-61.

Bigler, B. S., D. W. Welch, and J. H. Helle. 1996. A review of size trends among North Pacific salmon (Oncorhynchus spp.). Canadian Journal of Fisheries and Aquatic Sciences 53:455-465.

Bilby, R. E., B. R. Fransen, and P. A. Bisson. 1996. Incorporation of nitrogen and carbon from spawning coho salmon into the trophic system of small streams: evidence from stable isotopes. Canadian Journal of Fisheries and Aquatic Sciences 53:164-173.
Bilton, T. H. 1980. Returns of adult coho salmon in relation to mean size and time at release of juveniles to the catch and the escapement. Canadian Technical Report of Fisheries and Aquatic Sciences 941:1-41.

Blair, G. R., D. E. Rogers, and T. P. Quinn. 1993. Variation in life history characteristics and morphology of sockeye salmon in the Kvichak River system, Bristol Bay, Alaska. Transactions of the American Fisheries Society 122:550-559.

Blouin, M. 2003. Relative reproductive success of hatchery and wild steelhead in the Hood River. Final Report to Bonneville Power Administration, Contract 9245, Project 1988-053-12, Portland, Oregon.

Bosch, B. 2005. Appendix B: summary of data collected by the Yakama Nation relative to Yakima River spring Chinook salmon and the Cle Elum Spring Chinook Supplementation and Research Facility, 2004-2005. Annual Report, Bonneville Power Administration, Portland, Oregon.

Brannon, E. 1987. Mechanisms stabilizing salmonid fry emergence timing. Canadian Special Publication Fisheries and Aquatic Sciences 96:120-124.

Brannon, E. L., M. S. Powell, T. P. Quinn, and A. Talbot. 2004. Population structure of Columbia River Basin Chinook salmon and steelhead trout. Reviews in Fisheries Science 12:99-232.

Busack, C., and A. Marshall. 1991. Genetic analysis of YFP Chinook salmon stocks. Pages 2-45 in C. Busack, C. Knudsen, A. Marshall, S. Phelps, and D. Seiler editors. Yakima hatchery experimental design. Progress Report to Bonneville Power Administration, Contract DE-B17989BP00102, Portland, Oregon.

Busack, C., B. Watson, T. Pearsons, C. Knudsen, S. Phelps, and M. Johnston. 1997. Spring Chinook supplementation monitoring plan. Report to Bonneville Power Administration, DOE/BP 64878-1, Portland, Oregon.

Carmichael, R. W., and R. T. Messmer. 1995. Status of supplementing Chinook salmon natural production in the Imnaha River basin. Pages 284-291 in Uses and effects of cultured fishes in aquatic ecosystems, J. H. L. Schramm and R. G. Piper, editors. American Fisheries Society, Symposium 15, Bethesda, Maryland.

Dupont-Nivet, M., M. Vandeputte, P. Haffray, and B. Chevassus. 2006. Effect of different mating designs on inbreeding, genetic variance, and response to selection when applying individual selection in fish breeding programs. Aquaculture 252:161-170.

Einum, S., and I. A. Fleming. 2000. Selection against late emergence and small offspring in Atlantic salmon (Salmo salar). Evolution 54(2):628-640.

Fast, D. E., and C. Craig. 1997. Innovative hatchery project working to rebuild wild salmon populations. Hydrological Review 14:30-33.

Fiumera, A. C., B. A. Porter, G. Looney, M. A. Asmussen, and J. C. Avise. 2004. Maximizing offspring production while maintaining genetic diversity in supplemental breeding programs of highly fecund managed species. Conservation Biology 18(1):94-101.

Fleming, I. A., and M. R. Gross. 1993. Breeding success of hatchery and wild coho salmon (Oncorhynchus kisutch) in competition. Ecological Applications 3:167-185.

Fleming, I. A., K. Hindar, I. B. Mjolnerod, B. Jonsson, T. 
Balstad, and A. Lamberg. 2000. Lifetime success and interactions of farm salmon invading a native population. Proceedings of the Royal Society of London. B 267:1517-1523.

Foote, C. J. 1990. An experimental comparison of male and female spawning territoriality in a Pacific salmon. Behavior 115:283-314.

Ford, M. 2002. Selection in captivity during supportive breeding may reduce fitness in the wild. Conservation Biology 16(3):815-825.

Fresh, K. L., S. L. Schroder, E. C. Volk, J. Grimm, and M. Mizell. 2003. Evaluation of the Cedar River Sockeye salmon hatchery: analyses of adult otolith recoveries. Report to Washington Department of Fish and Wildlife, Olympia.

Gallinat, M. 2004. Tucannon River spring Chinook salmon hatchery evaluation program. Washington Department Fish and Wildlife, 2003 Annual Report to Bonneville Power Administration, Portland, Oregon.

Gjerde, B., and T. Gjedrem. 1984. Estimates of phenotypic and genetic parameters for carcass traits in Atlantic salmon and rainbow trout. Aquaculture 80:25-44.

Goodman, D. 2004. Salmon supplementation: demography, evolution, and risk assessment. Pages 217-232 in M. Nickum, P. Mazik, J. Nickum, and D. MacKinlay editors. Propagated fish in resource management. American Fisheries Society, Symposium 44, Bethesda, Maryland.

Goodman, D. 2005. Selection equilibrium for hatchery and wild spawning fitness in integrated breeding programs. Canadian Journal of Fisheries and Aquatic Sciences 62(2):374-389.

Hankin, D. G. 1990. Effects of month of release of hatcheryreared Chinook salmon on size at age, maturation schedule, and fishery contribution. Oregon Department of Fish and Wildlife, Information Report 90-4, Portland.

Hard, J. 1995. Genetic monitoring of life-history characters in salmon supplementation: problems and opportunities. Pages 212-225 in H. L. Schramm, Jr. and R. G. Piper editors. Uses and effects of cultured fishes in aquatic ecosystems. American Fisheries Society, Symposium 15, Bethesda, Maryland.

Hard, J. 2004. Evolution of Chinook salmon life history under size-selective harvest. Pages 316-337 in A. P. Hendry and S. C. Stearns editors. Evolution illuminated: salmon and their relatives. University Press, New York.

Healey, M. C. 1991. Life history of Chinook salmon (Oncorhynchus tshawytscha). Pages 311-393 in C. Groot and L. Margolis editors. Pacific salmon life histories. UBC Press, Vancouver.

Healey, M., and R. Heard. 1985. Inter- and intra-population variation in the fecundity of Chinook salmon (Oncorhynchus tshawytscha) and its relevance to life history theory. Canadian Journal of Fisheries and Aquatic Sciences 41:476-483.

Hendry, A. 2001. Adaptive divergence and the evolution of reproductive isolation in the wild: an empirical demonstration using introduced sockeye salmon. Genetica 112113:515-534.

Hendry, A. P., and T. P. Quinn. 1997. Variation in adult life history and morphology among Lake Washington sockeye salmon (Oncorhynchus nerka) populations in relation to habitat features and ancestral affinities.
Canadian Journal of Fisheries and Aquatic Sciences 54:75-84.

Hodgson, S., and T. P. Quinn. 2002. The timing of adult sockeye salmon migration into fresh water: adaptations by populations to prevailing thermal regimes. Canadian Journal of Zoology 80(3):542-555.

Keefer, M. L., C. A. Peery, M. A. Jepson, K. R. Tolotti, T. C. Bjornn, and L. C. Stuehrenberg. 2004. Stock-specific migration timing of adult spring-summer Chinook salmon in the Columbia River Basin. North American Journal of Fisheries Management 24(4):1145-1162.

Kinnison, M., M. Unwin, A. Hendry, and T. Quinn. 2001. Migratory costs and the evolution of egg size and number allocation in new and indigenous salmon populations. Evolution 55:1656-1667.

Knudsen, C. M., S. L. Schroder, M. V. Johnston, T. N. Pearsons, C. S. Busack, A. R. Marshall, C. R. Strom, and D. E. Fast. 2005. Life history and genetic traits of wild origin Yakima River spring Chinook salmon populations. Pages 29-61 in C. M. Knudsen, editor. Reproductive ecology of Yakima River hatchery and wild spring Chinook. Annual Report to Bonneville Power Administration, Portland, Oregon.

Lande, R. 1976. Natural selection and random genetic drift in phenotypic evolution. Evolution 30:314-334.

Lande, R. 1980. Genetic variation and phenotypic evolution during allopatric speciation. American Naturalist 116(4):463-479.

Lande, R., and S. J. Arnold. 1983. The measurement of selection on correlated characters. Evolution 37(6):1210 1226.

Larsen, D. A., B. R. Beckman, K. A. Cooper, D. Barrett, M. Johnston, P. Swanson, and W. W. Dickhoff. 2004. Assessment of high rates of precocious male maturation in a spring Chinook salmon supplementation hatchery program. Transactions of the American Fisheries Society 133:98-120.

Law, R. 1991. On the quantitative genetics of correlated characters under directional selection in age-structured populations. Philosophical Transactions of the Royal Society of London B 331:213-223.

Lichatowich, J. 1999. Salmon without rivers: a history of the Pacific salmon crisis. Island Press, Washington, D.C.

Lynch, M., and M. O'Hely. 2001. Captive breeding and the genetic fitness of natural populations. Conservation Genetics 2:363-378.

Major, R. L., and J. L. Mighell. 1969. Egg to migrant survival of spring Chinook (Oncorhynchus tshawytscha) in the Yakima River, Washington. Fishery Bulletin 67(2):347359.

Mobrand, L., J. Barr, H. L. Blankenship, D. E. Campton, T. T. P. Evelyn, T. Flagg, C. Mahnken, L. W. Seeb, P. R. Seidel, and W. W. Smoker. 2005. Hatchery reform in Washington State: principles and emerging issues. Fisheries 30(6):11-23.

Murdoch, A. R., T. N. Pearsons, T. W. Maitland, M. Ford, and K. Williamson. 2005. Monitoring the reproductive success of naturally spawning hatchery and natural spring Chinook salmon in the Wenatchee River. Annual Report to Bonneville Power Administration, 2003-03900, Portland, Oregon.

Nunney, L. 1991. The influence of age structure and fecundity 
on effective population size. Proceedings of the Royal Society of London B 246:71-76.

Pearsons, T. N. 2002. Chronology of ecological interactions associated with the life-span of salmon supplementation programs. Fisheries 27(12):10-15.

Pearsons, T. N., C. L. Johnson, B. B. James, and G. M. Temple. 2004. Spring Chinook salmon interactions indices and residual/precocial monitoring in the Upper Yakima Basin. Annual Report to the Bonneville Power Administration, 1995-063-25, Report DOE/BPA00013756-5, Portland, Oregon.

Prentice, E., T. A. Flagg, and C. S. Clinton. 1990. Equipment, methods, and an automated data-entry station for PIT tagging. Pages 335-340 in N. C. Parker, A. E. Giorgi, R. C. Heidinger, D. B. Jester, Jr., E. D. Prince, and G. A. Winans, editors. Fish-marking techniques. American Fisheries Society, Symposium Number 7, Bethesda, Maryland.

Quinn, T., and C. J. Foote. 1994. The effects of body size and sexual dimorphism on the reproductive behavior of sockeye salmon, Oncorhynchus nerka. Animal Behavior 48:751-761.

Quinn, T., J. Peterson, V. Gallucci, W. Hershberger, and E. Brannon. 2002. Artificial selection and environmental change: countervailing factors affecting the timing of spawning by coho and Chinook salmon. Transactions of the American Fisheries Society 131:591-598.

Riddell, B. E. 1986. Assessment of selective fishing on age at maturation in Atlantic salmon (Salmo salar): a genetic perspective. Pages 102-109 in D. J. Meerburg, editor. Salmonid age at maturity. Canadian Special Publication Fisheries and Aquatic Sciences 89.

Ricker, W. E. 1995. Trends in the average size of Pacific salmon in Canadian catches. Pages 593-602 in R. J. Beamish, editor. Climate change and northern fish populations. Canadian Special Publication Fisheries and Aquatic Sciences 121.

Rhodes, J. S., and T. P. Quinn. 1998. Factors affecting the outcome of territorial contests between hatchery and naturally reared coho salmon parr in the laboratory. Journal of Fish Biology 53:1220-1230.

Roff, D. 1992. The evolution of life histories. Theory and analysis. Chapman and Hall, New York.

Rogers, D. 1987. The regulation of age at maturity of Wood River sockeye salmon (Oncorhynchus nerka). Canadian Special Publication Fisheries and Aquatic Sciences 96:78-89.

Siitonen, L., and G. A. Gall. 1989. Response to selection for early spawn date in rainbow trout, Salmo gairdneri. Aquaculture 78:153-161.

Smoker, W., A. Gharrett, and M. Stekoll. 1998. Genetic variation of return date in a population of pink salmon: a consequence of fluctuating environment and dispersive selection? Alaska Fishery Research Bulletin 5:46-54.

Stearns, S. C. 1976. Life history tactics: a review of the ideas. Quarterly Review of Biology 51:3-47.

Stearns, S. C. 1989. The evolutionary significance of phenotypic plasticity. BioScience 39:436-445.

Steen, R. P., and T. P. Quinn. 1999. Egg burial depth by sockeye salmon (Oncorhynchus nerka): implications for survival of embryos and natural selection on female body size. Canadian Journal of Zoology 77:836-841.

Su, G., L. Liljedahl, and G. A. E. Gall. 2002. Genetic correlations between body weight at different ages and reproductive traits in rainbow trout. Aquaculture 213:8594.

Taylor, E. 1991. A review of local adaptation in Salmonidae, with particular reference to Pacific and Atlantic salmon. Aquaculture 98:185-207.

Unwin, M. J., and G. J. Glova. 1997. Changes in life history parameters in a naturally spawning population of Chinook salmon (Oncorhynchus tshawytscha) associated with releases of hatchery-reared fish. Canadian Journal of Fisheries and Aquatic Sciences 54(6):1235-1245.

U.S. Fish and Wildlife Service (USFWS). 2004. Upper Sacramento River winter Chinook salmon carcass survey 2003. Annual Report. U.S. Fish and Wildlife Service, Red Bluff, California.

van den Berghe, E. P., and M. R. Gross. 1989. Natural selection resulting from female breeding competition in a Pacific salmon (Coho: Oncorhynchus kisutch). Evolution 43:125-140.

Vøllestad, L. A., J. Peterson, and T. P. Quinn. 2004. Effects of freshwater and marine growth rates on early maturity in male coho and Chinook salmon. Transactions of the American Fisheries Society 133(3):495-503.

WDFW (Washington Department of Fish and Wildlife) and ODFW (Oregon Department of Fish and Wildlife). 2002. Columbia River fish runs and fisheries: 19382000. WDFW, Vancouver, and ODFW, Portland.

Waples, R. S., M. J. Ford, and D. Schmitt. 2001. Empirical results of salmon supplementation: a preliminary assessment. In T. Bert, editor. Ecological and genetic implications of aquaculture activities. Kluwer Academic Publishers, Dordrecht, The Netherlands.

Waples, R. S. 2002. Effective size of fluctuating salmon populations. Genetics 161:783-791.

Wells, B. K., C. B. Grimes, J. C. Field, and C. S. Reiss. 2006. Covariation between the average lengths of mature coho (Oncorhynchus kisutch) and Chinook salmon (O. tshawytscha) and the ocean environment. Fisheries Oceanography $15(1): 67-79$.

Zar, J. 1999. Biostatistical analysis, 4th edition. Prentice-Hall, Upper Saddle River, New Jersey. 